\title{
Halysioncum kishiense sp. n. and Echinobothrium parsadrayaiense sp. n. (Cestoda: Diphyllidea) from the banded eagle ray, Aetomylaeus cf. nichofii off the Iranian coast of the Persian Gulf
}

\author{
Mahdis Meraji Masouleh Moghadam and Mohammad Haseli
}

Department of Biology, Faculty of Sciences, University of Guilan, Rasht, Iran

\begin{abstract}
Two new species of two genera of the order Diphyllidea van Beneden in Carus, 1863, Halysioncum Caira, Marques, Jensen, Kuchta et Ivanov, 2013 and Echinobothrium van Beneden, 1849 sensu stricto are described from Aetomylaeus cf. nichofii (Bloch et Schneider) off the Iranian coast of the Persian Gulf. Halysioncum kishiense sp. n. differs from all other congeners in the number of apical hooks with the exception of H. hoffmanorum (Tyler, 2001) and H. pigmentatum (Ostrowski de Núñez, 1971). Halysioncum kishiense sp. n. can be easily differentiated from H. hoffmanorum and H. pigmentatum by the number of hooklets and testis numbers. Echinobothrium parsadrayaiense sp. n. is differentiated from all its congeners except for E. acanthinophyllum Rees, 1961 by its hook formula. The number of spines per column on the cephalic peduncle, the number of testes and possession of a thickwalled rather than thin-walled vagina distinguish E. parsadrayaiense sp. n. from E. acanthinophyllum. To date, with these two new species, five species of Diphyllidea have been reported from the Persian Gulf.
\end{abstract}

Keywords: new species, tapeworms, elasmobranchs, Myliobatidae, Bandar Lengeh, new geographical record, Parsa Draya, spiral intestine, parasites

This article contains supporting information (Figure S1) online at http://folia.paru.cas.cz/suppl/2014-61-2-133.pdf

Diphyllidea van Beneden in Carus, 1863, one of the exclusively marine cestode orders (Caira and Reyda 2005), consists of 54 valid species (Caira et al. 2013a,b, Ivanov and Caira 2013). One of the three main treatments of this order carried out by Khalil (1994) considered three families for this order, Echinobothriidae Perrier, 1897, Ditrachybothridiidae Schmidt, 1970 and Macrobothridiidae Khalil et Abdul-Salam, 1989. Then, Tyler (2006), based on phylogeny, recognised two monotypic families, Echinobothriidae with its single genus Echinobothrium van Beneden, 1849 and Ditrachybothridiidae with its single genus Ditrachybothridium Rees, 1959, suppressed the family Macrobothridiidae and transferred its species to Echinobothriidae.

After the erection of a new genus, Ahamulina Marques, Jensen et Caira, 2012, allocated to the family Echinobothriidae, the order Diphyllidea was revised by Caira et al. (2013a). In their revision, five genera namely Ahamulina; Halysioncum Caira, Marques, Jensen, Kuchta et Ivanov, 2013; Coronocestus Caira, Marques, Jensen, Kuchta et Ivanov, 2013; Ditrachybothridium; and Echinobothrium van Beneden, 1849 sensu stricto (s. s.), were recognised. Members of Echinobothrium s. s. and Halysioncum have many morphological similarities except for the arrangement of their hooklets. While the unique characteristic of the species of Echinobothrium s. s. is that the lateral hooklets are arranged in two separated clusters on either side of the dorsal and ventral apical hooks, members of the genus Halysioncum have a single continuous band of lateral hooklets on either side of the dorsal and ventral apical hooks. After the recognition of Echinobothrium s. s. and Halysioncum, four other species of these two genera have been described (Caira et al. 2013b, Ivanov and Caira 2013).

The Persian Gulf is a semi-closed ecosystem surrounded by Iran and the Arabian Peninsula. It is connected to the Gulf of Oman by the Strait of Hormuz which is the only sea passage from the Persian Gulf to the Indian Ocean. This water body possesses a great diversity of sharks and rays (Assadi and Dehghani 1997, Carpenter et al. 1997, Moore 2011, Valinasab 2013) and recently, has been on the site of faunistic studies of cestodes of elasmobranchs (see Haseli et al. 2010, 2011, 2012, Malek et al. 2010, Caira et al. 2011, Haseli 2013). To date, three species of the order Diphyllidea have been described from this region, of which two belonged to the genus Echinobothrium s. s. (Khalil and Abdul-Salam 1989, Haseli et al. 2012) and the other is a species of Coronocestus. This study describes new species of Echinobothrium s. s. and Halysioncum from Aetomylaeus cf. nichofii (Bloch

Address for correspondence: M. Haseli, Department of Biology, Faculty of Sciences, University of Guilan, 4193833697 Rasht, Iran. Phone/Fax: 981 313233 647; E-mail: haseli@guilan.ac.ir 
et Schneider) (see Supplementary Fig. S1) off the Iranian coast of the Persian Gulf.

\section{MATERIALS AND METHODS}

In December 2011, a total of 26 specimens of Aetomylaeus cf. nichofii (15 males and 11 females; body weight $0.9-4.0 \mathrm{~kg}$ ) were caught by local fishermen from the coast of Bandar Lengeh, Iran. Each spiral intestine was removed, opened longitudinally and placed into a plastic bag with $10 \%$ seawater-buffered formalin. Isolated worms were stored in $70 \%$ ethanol and then stained with acetic carmine, dehydrated in an ethanol series, cleared in methyl salicylate and mounted on slides in Canada balsam.

For examination with scanning electron microscopy (SEM), the mounted worms were studied under microscope and then the best specimens were demounted using xylene. These specimens were then hydrated, stored in $1 \%$ osmium tetroxide for 20 hours at $4{ }^{\circ} \mathrm{C}$, dehydrated in an ethanol series and dried in hexamethyldisilazane. The dried specimens were mounted on stubs, coated with gold and examined in a Vega II Tescan-LMU.

For microtriches, the terminology of Chervy (2009) was used. Hook formula follows Neifar et al. (2001) as modified by Kuchta and Caira (2010). Classification follows Caira et al. (2013a). A drawing tube attached to an hp NP-21 microscope was used for making drawings. Measurements taken by ocular micrometre are in micrometres unless otherwise stated and presented in the text as the range followed with the mean, standard error, number of cestodes examined $(\mathrm{N})$ and total number of measurements (n) in parentheses.

The specimens have been deposited in the Museum für Naturkunde Berlin (ZMB) and the helminthological collection of the Institute of Parasitology, BC ASCR, České Budějovice, Czech Republic (IPCAS).

\section{RESULTS}

\section{Halysioncum kishiense sp. n.}

Figs. 1, 2

Description (based on whole mounts of 7 mature specimens; 1 worm examined by SEM): Small worms, 0.7-1.5 mm (1.0 $\pm 0.14 \mathrm{~mm}, \mathrm{~N}=5)$ long. Scolex bipartite, consisting of scolex proper and cephalic peduncle. Scolex proper 98-124 (111 $\pm 4, \mathrm{~N}=6)$ long, consisting of armed apical rostellum and 1 dorsal and 1 ventral bothrium (Fig. 1A). Bothria round, 90-110 $(99 \pm 2, \mathrm{~N}=7, \mathrm{n}=13)$ long, 76-112 (95 $\pm 10, \mathrm{~N}=3)$ wide.

Apical hooks solid in two dorso-ventral groups, central A hooks shorter than adjacent hooks, B hooks gradually increasing in length toward centre of group, type B symmetry (Fig. 1B). Hook lengths shown in Table 1. Lateral hooklets arranged in single continuous row, 12-21 (16, $\mathrm{N}=4, \mathrm{n}=27$ ) long (Fig. 1C), hook formula $\{(9-12)$ $10-11 / 9\}$. Cephalic peduncle $129-176(155 \pm 7, \mathrm{~N}=7)$ long, 38-58 $(47 \pm 5, \mathrm{~N}=4)$ wide, armed with 8 longitudinal columns of $16-20(17, \mathrm{~N}=7, \mathrm{n}=18)$ spines, spines with triradiate bases, decreasing in length posteriorly, 5-46 $(30 \pm 3, \mathrm{~N}=7, \mathrm{n}=24)$ long (Fig. 1A,D).

Distal bothrial surfaces with conspicuous central triangular region with papilliform filitriches (Fig. 2B,C,F,G),
Table 1. Halysioncum kishiense sp. n., hook lengths $(\mu \mathrm{m})$. For each hook, the number of cestodes examined $(\mathrm{N})$ and the total number of measurements (n) are given.

\begin{tabular}{cccc}
\hline A hooks & Range (mean $\pm \mathrm{SE})$ & B hooks & Range (mean $\pm \mathrm{SE})$ \\
\hline $1(10-11)$ & $(45 \pm 1, \mathrm{~N}=4, \mathrm{n}=6)$ & $1^{\prime}\left(9^{\prime}\right)$ & $(48 \pm 1, \mathrm{~N}=4, \mathrm{n}=5)$ \\
& $46-55$ & & $45-53$ \\
$2(9)$ & $(49 \pm 2, \mathrm{~N}=3, \mathrm{n}=4)$ & $2^{\prime}\left(8^{\prime}\right)$ & $(53 \pm 2, \mathrm{~N}=4, \mathrm{n}=5)$ \\
$3(8)$ & $(52 \pm 2, \mathrm{~N}=3, \mathrm{n}=4)$ & $3^{\prime}\left(7^{\prime}\right)$ & $(55 \pm 2, \mathrm{~N}=4, \mathrm{n}=5)$ \\
$4(7)$ & $(51 \pm 2, \mathrm{~N}=3, \mathrm{n}=5)$ & $4^{\prime}\left(6^{\prime}\right)$ & $(57 \pm 2, \mathrm{~N}=4, \mathrm{n}=5)$ \\
$5(6)$ & $(48 \pm 4, \mathrm{~N}=2, \mathrm{n}=4)$ & $5^{\prime}$ & $(59 \pm 2, \mathrm{~N}=4, \mathrm{n}=5)$ \\
\hline
\end{tabular}

remainder of distal surfaces covered with trifurcate spinitriches with long digits (Fig. 2D,E). Proximal bothrial surfaces covered with trifid spinitriches on anterior surface (Fig. 2H), palmate spinitriches with 5 and 6 digits interspersed with papilliform filitriches on middle surface (Fig. 2I) and palmate spinitriches with 4-8 digits interspersed with papilliform filitriches on posterior surface (Fig. 2J); posteriormost proximal surfaces with sparse palmate spinitriches with 6-8 digits interspersed with papilliform filitriches (Fig. 2K); Cephalic peduncle with papilliform and acicular filitriches; acicular filitriches become more dense toward posterior surface (Fig. 2L,M); Proglottids with acicular filitriches (Fig. 2N).

Strobila apolytic, acraspedote, with 5-6 ( $\mathrm{N}=5)$ proglottids. Immature proglottids $4-5(\mathrm{~N}=5)$ in number, initially wider than long, becoming longer than wide with maturity (Fig. 1A). Mature proglottids $1-2(\mathrm{~N}=5)$ in number (Fig. 1A,E), 351-651 (507 $\pm 51, \mathrm{~N}=5)$ long, 102-180 (137 $\pm 15, \mathrm{~N}=5)$ wide, length/width ratio $1: 3.2-6.2(3.9 \pm 0.6, \mathrm{~N}=5)$. Testes $10-11(10, \mathrm{~N}=4)$ in number, 43-80 (61 $\pm 3, \mathrm{~N}=3, \mathrm{n}=9)$ long, 30-52 (40 \pm 3 , $\mathrm{N}=3, \mathrm{n}=9$ ) wide, arranged in 2 irregular columns, from anterior margin of proglottid to cirrus sac (Fig. 1A,E). Vas deferens extensive, extending laterally to cirrus sac (Fig. 1E,F). Cirrus sac pyriform, 44-105 $(80 \pm 13, \mathrm{~N}=4)$ long, 39-71 (55 $\pm 6, \mathrm{~N}=4)$ wide, length/width ratio $1: 1.1-2.1(1.4 \pm 0.2, \mathrm{~N}=4)$. Cirrus armed with spinitriches, spinitriches $3-10(6 \pm 1, \mathrm{~N}=2, \mathrm{n}=10)$ long in mature proglottid (Figs. 1E, F). Seminal vesicle absent.

Ovary posterior, H-shaped in frontal view, ovarian lobe 105-162 (133 $\pm 9, \mathrm{~N}=4, \mathrm{n}=7)$ long (Fig. 1E). Mehlis' gland posterior to ovarian isthmus, $41(\mathrm{~N}=1)$ long, $36(\mathrm{~N}=1)$ wide. Genital pore postequatorial, midventral, 120-202 $(170 \pm 18, \mathrm{~N}=4)$ from posterior end of proglottid, 32-40\% (36 $\pm 2, \mathrm{~N}=4)$ of proglottid length from posterior end of proglottid (Fig. 1E,F). Vagina muscular, $17-20(19 \pm 1, N=2)$ in diameter. Uterus saccate, thickwalled in early stages of development (Fig. 1A,E). Vitellarium follicular, follicles $12-41(24 \pm 3, \mathrm{~N}=4, \mathrm{n}=8)$ long, 11-32 $(17 \pm 2, \mathrm{~N}=4, \mathrm{n}=10)$ wide, forming two lateral bands, each band consisting of 1 dorsal and 1 ven- 
A
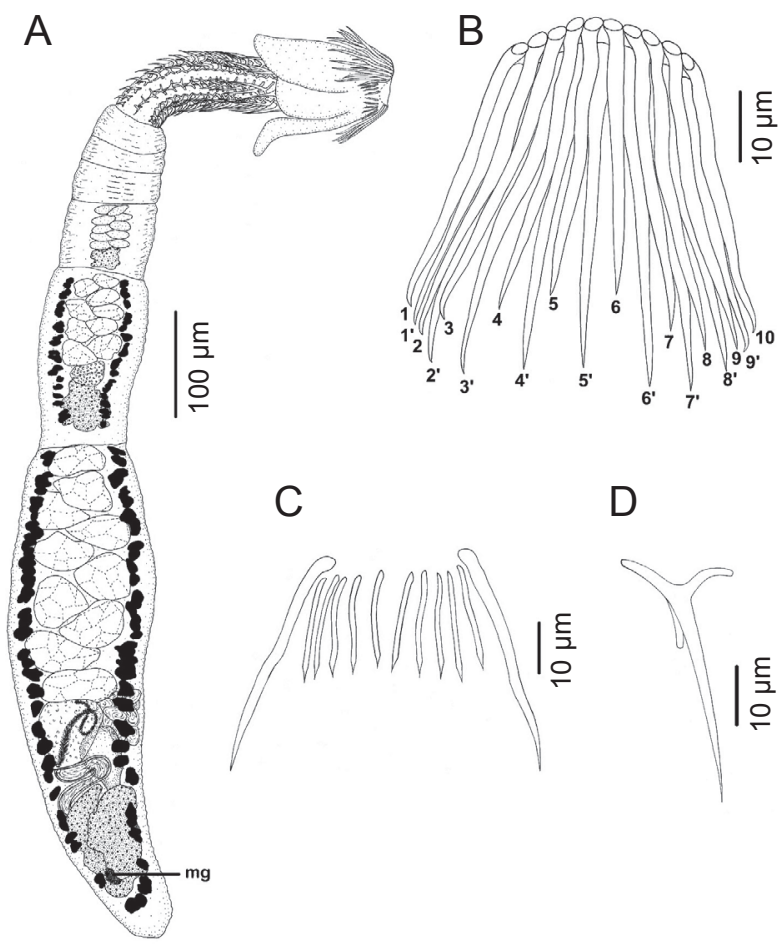

D

G

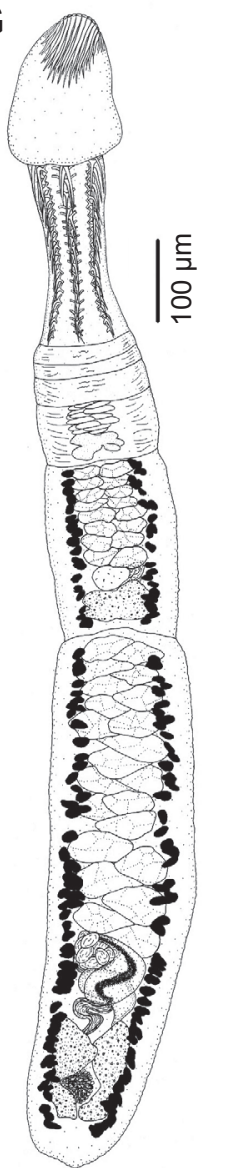

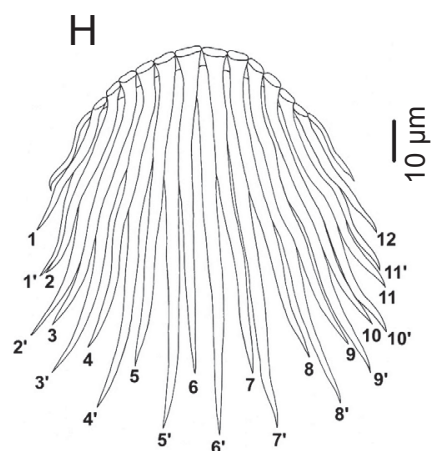
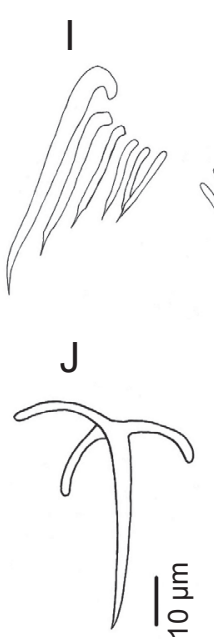

\section{$\mathrm{K}$}
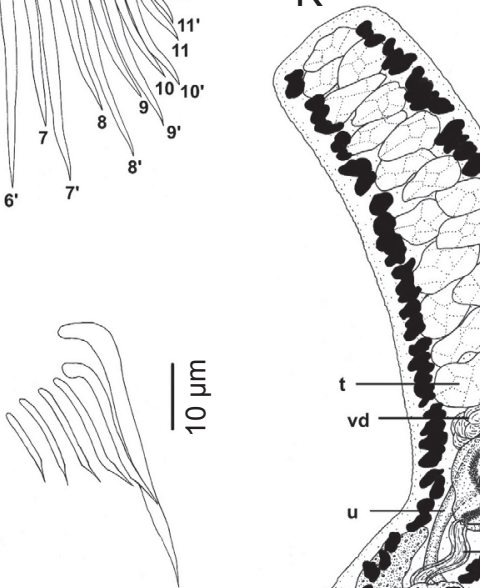

| $\frac{\xi}{2}$
$\mathrm{F}$

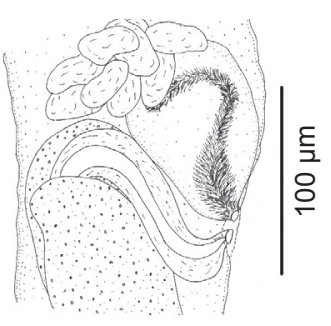

$\mathrm{L}$

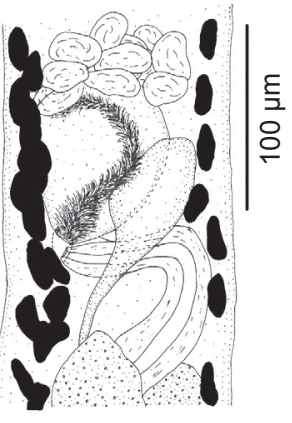

Fig. 1A-F. Line drawings of Halysioncum kishiense sp. n. from Aetomylaeus cf. nichofii. A - whole worm; B - apical hooks; $\mathbf{C}$ - a single band of hooklets; D - spine on the cephalic peduncle; $\mathbf{E}$ - mature proglottid, lateral view; $\mathbf{F}$ - detail of terminal genitalia in lateral view. In Fig. 1E,F, for the lateral view of proglottid, vitelline follicles are not shown. Fig. 1G-L. Line drawings of Echinobothrium parsadrayaiense sp. n. from Aetomylaeus cf. nichofii. $\mathbf{G}$ - whole worm; H - apical hooks; I - hooklets; J - spine on the cephalic peduncle; $\mathbf{K}$ - mature proglottid; $\mathbf{L}$ - detail of terminal genitalia. Abbreviations: cs - cirrus-sac; ga - genital atrium; $\mathrm{mg}$ - Mehlis' gland; o - ovary; $\mathrm{t}$ - testis; $\mathrm{u}$ - uterus; $\mathrm{v}$ - vagina; vd - vas deferens. 

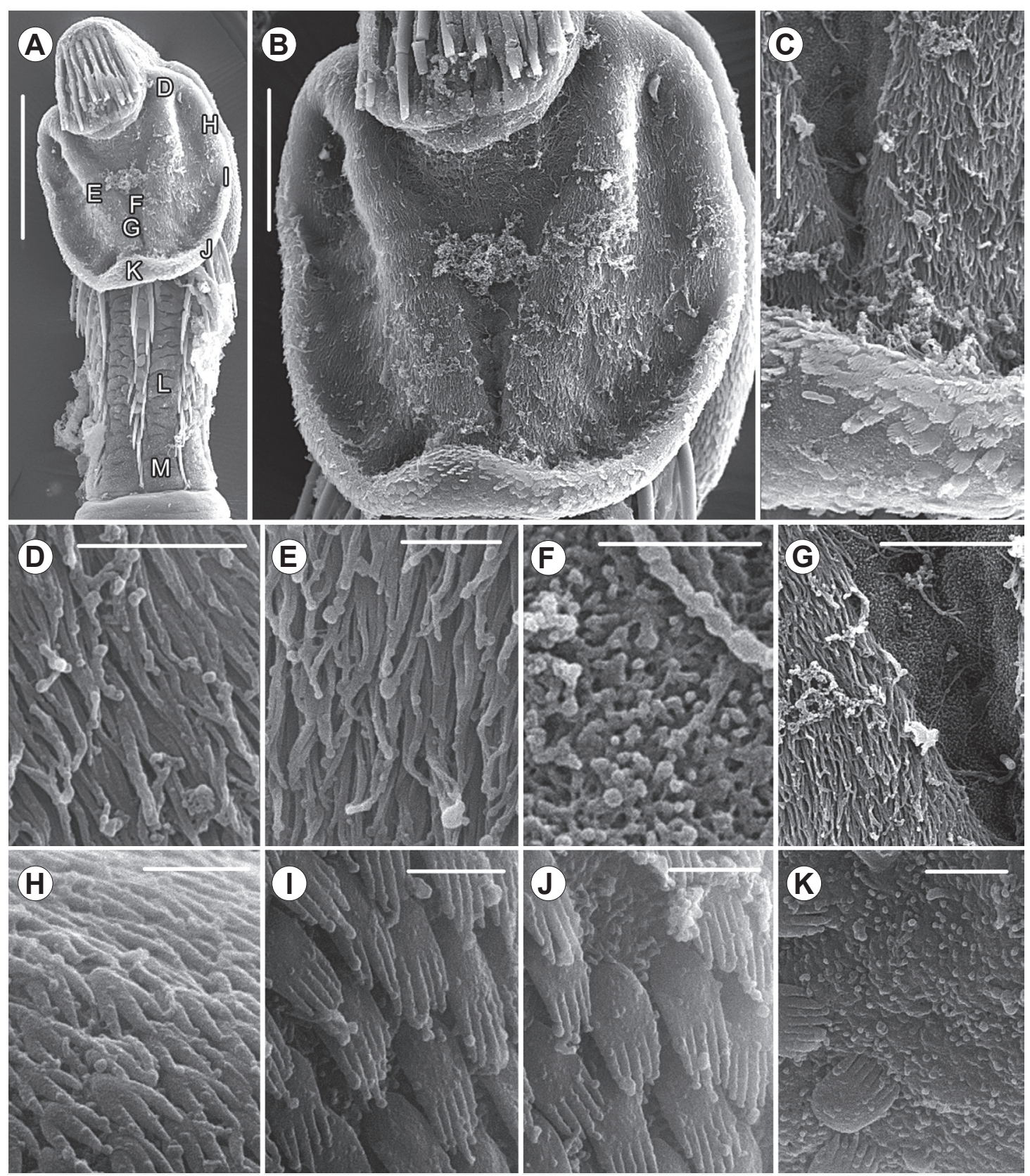

(K)
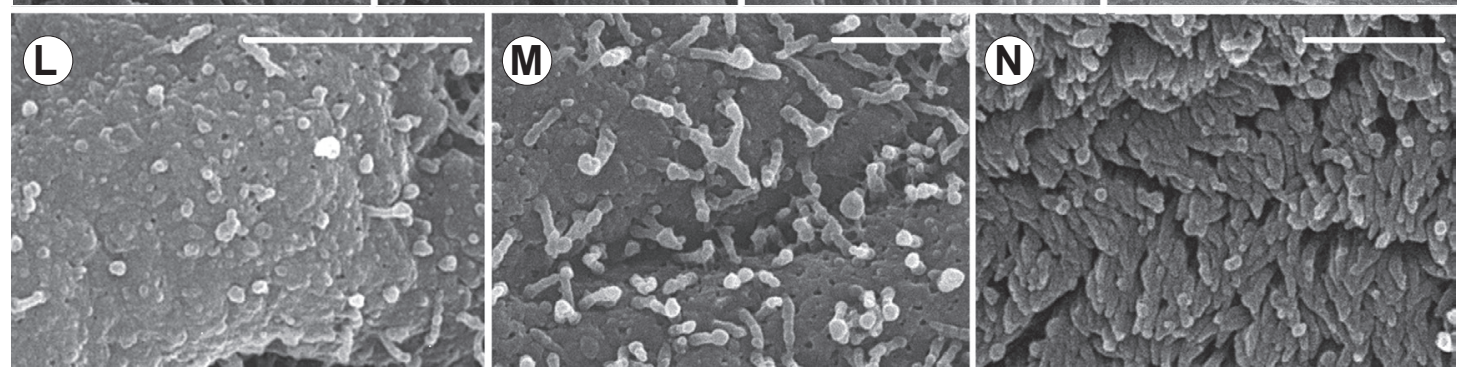

Fig. 2. Scanning electron micrographs of Halysioncum kishiense sp. n. from Aetomylaeus cf. nichofii. A - scolex; B - bothrium; $\mathbf{C}$ - central triangular region of bothrium; D- $\mathbf{G}$ - distal bothrial surface; $\mathbf{H}-\mathbf{J}$ - proximal bothrial surface; $\mathbf{K}$ - medial line of posterior-most proximal surfaces; $\mathbf{L}$ - middle surface of cephalic peduncle; $\mathbf{M}$ - posterior surface of cephalic peduncle; $\mathbf{N}$ - proglottid. Scale bars: $A=50 \mu \mathrm{m} ; \mathrm{B}=20 \mu \mathrm{m} ; \mathrm{C}, \mathrm{G}=5 \mu \mathrm{m} ; \mathrm{D}=2 \mu \mathrm{m} ; \mathrm{E}, \mathrm{F}, \mathrm{H}-\mathrm{N}=1 \mu \mathrm{m}$. Small numbers in Fig. 2A indicate locations of details shown in Fig. 2D-M. 
tral column of follicles, columns extending entire length of proglottid, uninterrupted by ovary.

Type host: Aetomylaeus cf. nichofii (Bloch et Schneider) (Myliobatiformes: Myliobatidae).

Type locality: Off the coast of Bandar Lengeh, Persian Gulf (263'ㄹ' $\mathrm{N}$; 54 52'50"E).

Site in host: Spiral intestine.

Prevale nce : 46\% (12 of 26 individuals examined).

Mean intensity: 3 (1-10 worms per host).

Type material: Holotype in IPCAS (C - 643; 1 slide); paratypes in ZMB (ZMB E.7573; 2 slides) and IPCAS (C $-643 ; 5$ slides with 4 specimens). One paratype prepared for SEM retained in the Natural History Museum of Iran, Teheran, Iran (MMTT K. 4174).

Etymology: The specific name 'kishiense' is derived from Kish, one of the Iranian islands close to Bandar Lengeh.

Remarks. The number of apical hooks distinguishes Halysioncum kishiense sp. n. from all other species in the genus except Halysioncum hoffmanorum (Tyler, 2001) Caira, Marques, Jensen, Kuchta et Ivanov, 2013 and Halysioncum pigmentatum (Ostrowski de Núñez, 1971) Caira, Marques, Jensen, Kuchta et Ivanov, 2013. Halysioncum kishiense differs from $H$. hoffmanorum in possessing fewer lateral hooklets (9-12 vs 12-22) and 10-11 testes arranged in two columns vs 4-8 testes arranged in single column.

In addition, these two species are different from each other in size and pattern of microtriches. Whereas the bothrium of $H$. kishiense is covered with trifid spinitriches, palmate spinitriches, trifurcate spinitriches and papilliform filitriches, the bothrium of $H$. hoffmanorum is covered with pectinate spinitriches and papilliform filitriches. The new species can be differentiated from $H$. pigmentatum in the possession of 9-12 vs 20-22 hooklets, number of testes columns (two columns vs single column) and testes number (10-11 vs 5-7).

\section{Echinobothrium parsadrayaiense sp. n. Figs. 1, 3}

Description (based on whole mounts of 13 mature specimens and 1 fully gravid specimen; 4 worms examined by SEM): Worms $1.0-2.7 \mathrm{~mm}(1.7 \pm 0.1 \mathrm{~mm}$, $\mathrm{N}=13)$ long. Strobila apolytic, acraspedote, 5-7 (6, N $=12$ ) proglottids. Scolex bipartite, consisting of scolex proper and cephalic peduncle. Scolex proper 129-195 (148 $\pm 6, \mathrm{~N}=12$ ) long, consisting of armed apical rostellum and one dorsal and one ventral bothrium (Fig. 1G). Bothria round, 112-156 (128 $\pm 5, \mathrm{~N}=11)$ long, 98-158 $(127 \pm 6, \mathrm{~N}=9)$ wide. Rostellum bears 1 dorsal and 1 ventral group of $23(\mathrm{~N}=9)$ large solid hooks flanked on each side by $3-5(4, \mathrm{~N}=8, \mathrm{n}=16)$ smaller lateral hooklets, hook formula $\{3-512 / 113-5\}$, with type B symmetry (Fig. 1H,I).

Apical hooks gradually increase in length toward centre of group. Hook lengths shown in Table 2. Lateral hooklets in two groups, $12-22(16 \pm 1, \mathrm{~N}=7, \mathrm{n}=22)$ long
Table 2. Echinobothrium parsadrayaiense sp. n., hook lengths $(\mu \mathrm{m})$. For each hook, the number of cestodes examined $(\mathrm{N})$ and the total number of measurements (n) are given.

\begin{tabular}{cccc}
\hline A hooks & Range (mean \pm SE) & B hooks & Range (mean \pm SE) \\
\hline $1(12)$ & $24-42$ & $1^{\prime}\left(11^{\prime}\right)$ & $(40 \pm 1, \mathrm{~N}=9, \mathrm{n}=17)$ \\
& $(34 \pm 1, \mathrm{~N}=9, \mathrm{n}=16)$ & & $48-68$ \\
$2(11)$ & $(48 \pm 6, \mathrm{~N}=60$ & $2^{\prime}\left(10^{\prime}\right)$ & $(55 \pm 1, \mathrm{~N}=9, \mathrm{n}=17)$ \\
$3(10)$ & $47-71$ & & $57-78$ \\
& $(59 \pm 2, \mathrm{~N}=8, \mathrm{n}=16)$ & $3^{\prime}\left(9^{\prime}\right)$ & $(66 \pm 7, \mathrm{~N}=8, \mathrm{n}=16)$ \\
$4(9)$ & $(64 \pm 2, \mathrm{~N}=6, \mathrm{n}=12)$ & $4^{\prime}\left(8^{\prime}\right)$ & $(73 \pm 1, \mathrm{~N}=62, \mathrm{n}=12)$ \\
$5(8)$ & $(66 \pm 1, \mathrm{~N}=5, \mathrm{n}=10)$ & $5^{\prime}\left(7^{\prime}\right)$ & $(74 \pm 1, \mathrm{~N}=5, \mathrm{n}=10)$ \\
$6(7)$ & $64-71$ & $6^{\prime}$ & $74-79$ \\
& $(68 \pm 1, \mathrm{~N}=5, \mathrm{n}=10)$ & & $(76 \pm 1, \mathrm{~N}=5, \mathrm{n}=5)$ \\
\hline
\end{tabular}

(Fig. 1I). Cephalic peduncle 168-273 $(219 \pm 8, \mathrm{~N}=13)$ long, 54-78 $(68 \pm 2, \mathrm{~N}=12)$ wide, armed with 8 longitudinal columns of 19-24 $(\mathrm{N}=13, \mathrm{n}=30)$ spines, spines with triradiate bases, $8-48(25 \pm 2, \mathrm{~N}=13, \mathrm{n}=41)$ long (Figs. 1G,J, 3J), decreasing in length posteriorly.

Apex of scolex covered with capilliform and papilliform filitriches (Fig. 3C). Distal bothrial surfaces with conspicuous central triangular region with papilliform filitriches (Fig. 3B,I), remainder of distal surfaces covered with trifurcate spinitriches with long digits (Fig. 3D,E); Proximal bothrial surface with packed densely trifid spinitriches in anterior part (Fig. 3F); palmate spinitriches with 4, 5 and 6 digits interspersed with papilliform filitriches in middle surface (Fig. 3G); palmate spinitriches with 5, 6 and 7 digits interspersed with papilliform filitriches in posterior surface (Fig. 3H). Cephalic peduncle with acicular and papilliform filitriches (Fig. 3J-L); proglottids with acicular filitriches (Fig. 3M).

Immature proglottids $3-5(4, \mathrm{~N}=13)$ in number, initially wider than long, becoming longer than wide with maturity (Fig. 1G). Mature proglottids $1-2(\mathrm{~N}=12)$ in number, 545-1287 (855 $\pm 75, \mathrm{~N}=11)$ long, 119-257 $(175 \pm 12, \mathrm{~N}=13)$ wide, length/width ratio $1: 3.3-6.8$ $(4.8 \pm 0.4, \mathrm{~N}=9)$. Testes $57-84(71 \pm 9, \mathrm{~N}=12, \mathrm{n}=14)$ long, 20-48 (35 $\pm 2, \mathrm{~N}=12, \mathrm{n}=14)$ wide, arranged in 2 columns, $16-22(19 \pm 1, \mathrm{~N}=11)$ in number, anterior to cirrus sac (Fig. 1G,K). Vas deferens extensive (Fig. 1K,L), cirrus armed with spinitriches, spinitriches 2-6 (4 $\pm 1, \mathrm{~N}=2, \mathrm{n}=5)$ long in mature proglottid, 5-12 $(9 \pm 2, N=1, n=6)$ long in gravid proglottid. Cirrus sac pyriform, 91-145 (121 $\pm 7, \mathrm{~N}=8)$ long, 58-115 (87 \pm 7 , $\mathrm{N}=8$ ) wide, located anterior to ovary (Fig. $1 \mathrm{G}, \mathrm{K}, \mathrm{L}$ ); seminal vesicle absent.

Ovary posterior, H-shaped in dorsoventral view, ovarian lobes 96-238 (165 $\pm 16, \mathrm{~N}=9)$ long, 41-80 (60 \pm 3 , $\mathrm{N}=12, \mathrm{n}=14)$ wide. Mehlis' gland posterior to ovarian isthmus, 33-52 (46 $\pm 4, \mathrm{~N}=5)$ long, $22-49(33 \pm 4$, $\mathrm{N}=5$ ) wide; vagina thick-walled, relatively uniform in width, opening posterior to cirrus sac (Fig. 1K,L). Egg capsule round to ovoid, $10-20(16 \pm 2, \mathrm{~N}=1, \mathrm{n}=6)$ long, 

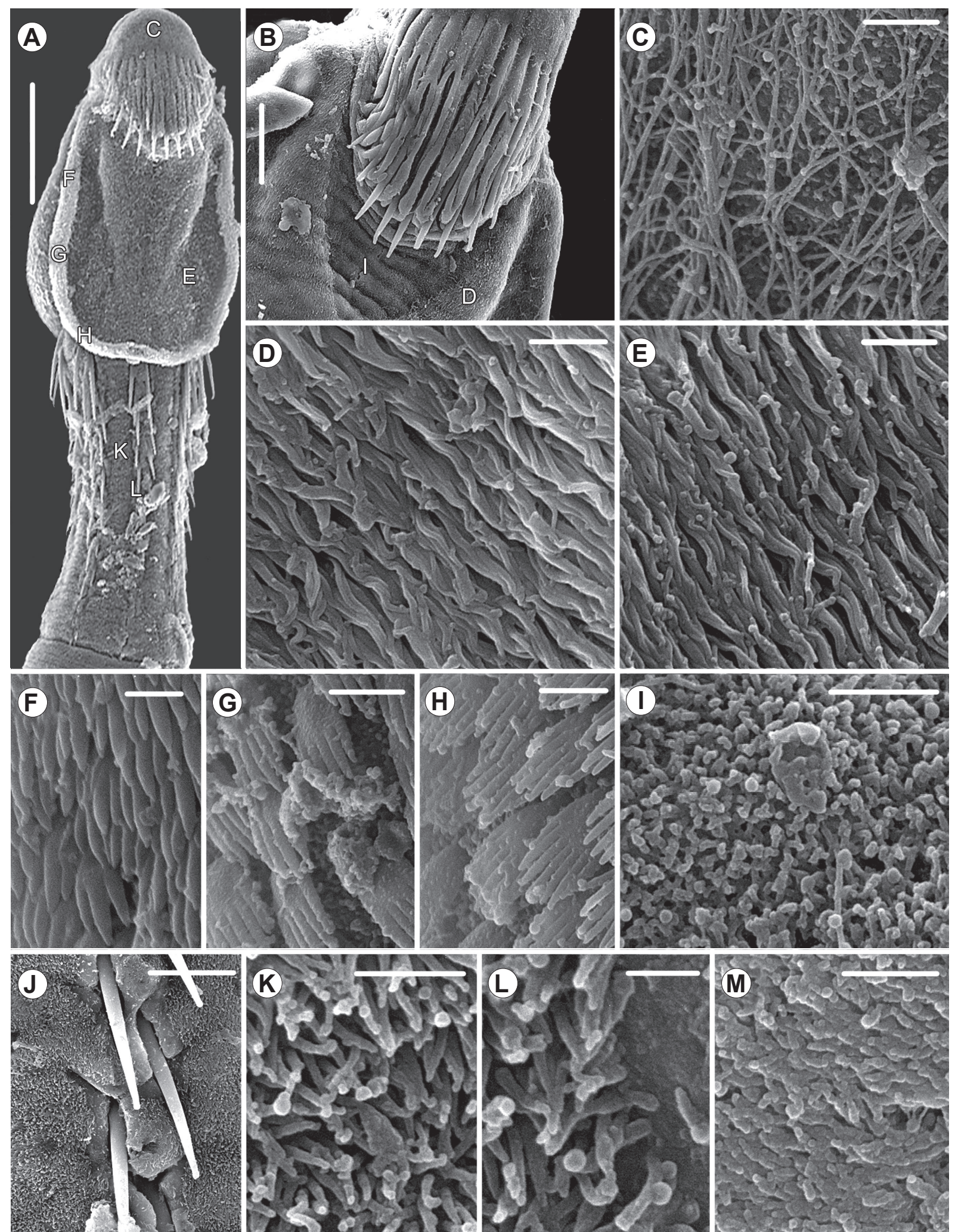

Fig. 3. Scanning electron micrographs of Echinobothrium parsadrayaiense sp. n. from Aetomylaeus cf. nichofii $\mathbf{A}-\mathrm{scolex} ; \mathbf{B}-$ apical hooks; C - apex; D, E, I - distal bothrial surface; $\mathbf{F}-\mathbf{H}$ - proximal bothrial surface; J-L - cephalic peduncle; $\mathbf{M}$ - proglottid. Scale bars: $A=50 \mu \mathrm{m} ; \mathrm{B}=20 \mu \mathrm{m} ; \mathrm{C}-\mathrm{F}, \mathrm{H}, \mathrm{I}, \mathrm{K}, \mathrm{M}=1 \mu \mathrm{m} ; \mathrm{G}, \mathrm{L}=0.5 \mu \mathrm{m} ; \mathrm{J}=10 \mu \mathrm{m}$. Small numbers in Fig. 3A,B indicate locations of details shown in Fig. 3C-L. 
10-15 (12 $\pm 1, \mathrm{~N}=1, \mathrm{n}=6)$ wide. Genital pore midventral, postequatorial, slightly anterior to ovary, 156-410 $(274 \pm 22, \mathrm{~N}=13)$ from posterior end of proglottid, $20-40 \%(32 \pm 3, \mathrm{n}=9)$ of proglottid length from posterior end of proglottid. Uterus saccate, thick-walled in early stages of development (Fig. 1K,L). Vitellarium follicular, follicles 19-45 $(29 \pm 3, \mathrm{~N}=9, \mathrm{n}=11)$ long, $11-24(18 \pm 1$, $\mathrm{N}=9, \mathrm{n}=11$ ) wide, vitelline follicles in 2 lateral bands, each band consisting of 1 dorsal and one ventral column of follicles, columns extending entire length of proglottid, uninterrupted by ovary (Fig. 1K). Gravid proglottids observed in one worm, $1287(\mathrm{~N}=1)$ long, $220(\mathrm{~N}=1)$ wide.

Type host: Aetomylaeus cf. nichofii (Bloch et Schneider) (Myliobatiformes: Myliobatidae).

Type locality: Off the coast of Bandar Lengeh, Persian

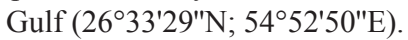

Site in host: Spiral intestine.

Prevalence: $58 \%$ ( 15 of 26 individuals examined).

Mean intensity: 5.3 (1-22 worms per host).

Type material: Holotype in IPCAS (C - 644; 1 slide); paratypes in IPCAS (C $-644 ; 10$ slides with 9 specimens) and ZMB (ZMB E.7572; 4 slides). Four paratypes prepared for SEM retained in the Natural History Museum of Iran, Teheran, Iran (MMTT P. 4174).

E ty mology: The specific name 'parsadrayaiense' is derived from Parsa Draya (old Persian: Parsa $=$ Persian and Draya $=$ sea), one of the oldest names for the Persian Gulf used by Darius the great, the king of the Persian Achaemenid Empire in the fifth century B.C.

Remarks. The hook formula in Echinobothrium parsadrayaiense $\mathrm{sp}$. n. distinguishes it from all other species in the genus except for E. acanthinophyllum Rees, 1961. The new species differs from $E$. acanthinophyllum in the number of spines per row on the cephalic peduncle (19-24 vs 10-13), the number of testes (16-22 vs 11-14) and possession of a thick-walled rather than thin-walled vagina.

\section{DISCUSSION}

Recently Naylor et al. (2012), based on DNA sequences, evaluated elasmobranch species and presented many cryptic species for this taxon. In the case of Aetomylaeus nichofii, they recognised three species located in three clades. The real A. nichofii is from Indonesia (type locality) and other two species, Aetomylaeus cf. nichofii 1 and Aetomylaeus cf. nichofii 2 occur in the Persian Gulf and Australia, respectively. Since the date of our sampling was before the publication of Naylor et al. (2012), no tissue was saved for future molecular identification of the hosts. However, the photographic record of the host clearly indicates that this ray with grayish blue bands belongs to $\mathrm{Ae}$ tomylaeus nichofii sensu lato (see Supplementary Fig. S1). Thus, we consider the host species to be $A$. cf. nichofii.

In the most comprehensive revision of the systematics of the order Diphyllidea, Caira et al. (2013a) pre- sented a new classification based on a phylogenetic tree constructed using DNA sequences. They erected the new genera, Halysioncum, based on the synapomorphy of a continuous band of lateral hooklets, Coronocestus, due to the presence of a corona of spines on the anterior part of bothria, and modified the diagnosis of Echinobothrium on the basis of the presence of clusters of lateral hooklets. However, their analysis included only 12 of the 50 valid species described at that time along with 19 undescribed species. Thus, considering the monophylies of relatively small numbers of described Echinobothrium sensu lato, three clades were proposed as new genera. In order to be certain of the monophyly of the erected genera, all species would have to be included in the molecular analysis. Increasing the number of species included in a phylogenetic analysis as well as the kind of analysis used may sometimes dramatically shift the tree topology and in turn taxonomic decisions. For example, adding only three species to the phylogenetic analysis of the order Trypanorhyncha Diesing, 1863 and using a different analysis resulted in a different topology (see Palm et al. 2009, Olson et al. 2010).

For the great majority of diphyllidean species, apical hooks increase in length toward centre of group (see Tyler 2006). In some species of Echinobothrium s. s. such as Echinobothrium helmymohamedi Saoud, Ramadan et Hassan, 1982, E. harfordi McVicar, 1976, E. elegans Tyler, 2001 and E. brachysoma Pintner, 1889, there is a different pattern for the length of apical hooks. Echinobothrium harfordi is one of the species in which the length of A hooks decreases toward the centre of the group. In the phylogenetic tree of Caira et al. (2013a), E. harfordi was in the Echinobothrium s. s. clade. Of the 16 valid species of Halysioncum, only three have apical hooks that decrease in length towards the centre: A hooks decrease in length in $H$. kishiense and $H$. arafurense Ivanov et Caira, 2013, and B hooks decrease in length in H. bonasum (William et Campbell, 1980) Caira, Marques, Jensen, Kuchta et Ivanov, 2013. Mapping the patterns of apical hook length on the phylogenetic tree of Caira et al. (2013a) indicates it is a homoplasious character.

In the type series of $H$. kishiense, 11 A hooks were seen in only one specimen, whereas the remaining specimens in the type series had only 10 . Variation in the number of A or B apical hooks among conspecifics is also observed in other species of the order, such as Echinobothrium euterpes (Neifar, Tyler et Euzet, 2001) Tyler, 2006, Echinobothrium rhynchobati (Khalil et Abdul-Salam, 1989) Tyler, 2006, Halysioncum hoffmanorum, Halysioncum nataliae (Kuchta et Caira, 2010) Caira, Marques, Jensen, Kuchta et Ivanov, 2013, Halysioncum raschii (Campbell et Andrade, 1997) Caira, Marques, Jensen, Kuchta et Ivanov, 2013 and Coronocestus diamanti (Ivanov et Lipshitz, 2006) Caira, Marques, Jensen, Kuchta et Ivanov, 2013. With additional sampling, we predict that diphyl- 
lideans currently considered to have a fixed hook formula may in fact show variation in their apical hook number.

The two new species described here may have been encountered off the coast of Qatar by Al Kawari et al. (1996), as that study reported several unidentified specimens belonging to Echinobothrium sensu lato from $A$. nichofii. However, no cestode specimens were deposited and the identity of the host species cannot be verified.
Therefore, it is impossible to know what species were found. It is likely there is more diphyllidean diversity to be discovered in this region given the rich fauna of potential elasmobranch hosts, especially batoids and triakids, in the Persian Gulf.

Acknowledgements. Thanks are due to Dr. Nader Shabanipour, Dr. Akbar Norastehnia and Mrs. Mahvash Hadavi who provided laboratory facilities.

\section{REFERENCES}

Al Kawari K.S.R., Saoud M.F.A., Ramadan M.M. 1996: Biodiversity of helminth parasites of fishes in the Arabian Gulf, with special reference to digenetic trematodes and cestodes. Qatar Univ. Sci. J. 16: 141-153.

Assadi H., Dehghani R. 1997: Atlas of the Persian Gulf and the Sea of Oman fishes. Iranian Fisheries Research and Training Organization, Tehran, $226 \mathrm{pp}$.

Caira J.N., Malek M., Ruhnke T. 2011: A new genus of Phyllobothriidae (Cestoda: Tetraphyllidea) in carcharhiniform sharks from Iran and Australia. J. Helminthol. 85: 40-50.

Caira J.N., Marques F.P., Jensen K., Kuchta R., Ivanov V.A. 2013a: Phylogenetic analysis and reconfiguration of genera in the cestode order Diphyllidea. Int. J. Parasitol. 43: 621-639.

Caira J.N., Reyda B. 2005: Eucestoda (true tapeworms). In: K. Rohde (Ed.), Marine Parasitology. CSIRO Publishing, Melbourne and CABI Wallingford, pp. 22-104.

Caira J.N., Rodriguez N., Pickering M. 2013b: New African species of Echinobothrium (Cestoda: Diphyllidea) and implications for the identities of their skate hosts. J. Parasitol. 99: 781-788

Carpenter K.E., Krupp F., Jones D.A., Zajonz U. 1997: FAO species identification field guide for fishery purposes. Living marine resources of Kuwait, eastern Saudi Arabia, Bahrain, Qatar, and the United Arab Emirates. FAO, Rome, 293 pp.

Chervy L. 2009: Unified terminology for cestodes microtriches: a proposal from the participants of the International Workshops on Cestode Systematics in 2002-2008. Folia Parasitol. 56: 199-230.

Haseli M. 2013: Trypanorhynch cestodes from elasmobranchs from the Gulf of Oman, with the description of Prochristianella garshaspi n. sp. (Eutetrarhynchidae). Syst. Parasitol. 85: 271-279.

Haseli M., Malex M., Palm H.W. 2010: Trypanorhynch cestodes of elasmobranchs from the Persian Gulf. Zootaxa 2492: 28-48.

Haseli M., Malek M., Palm H.W., Ivanov V.A. 2012: Two new species of Echinobothrium van Beneden, 1849 (Cestoda: Diphyllidea) from the Persian Gulf. Syst. Parasitol. 82: 201-209.

Haseli M., Malek M., Valinasab T., Palm H.W. 2011: Trypanorhynch cestodes of teleost fish from the Persian Gulf, Iran. J. Helminthol. 85: 215-224.

Ivanov V.A., CaIra J.N. 2013: Two new species of Halysioncum Caira, Marques, Jensen, Kuchta et Ivanov, 2013 (Cestoda, Diphyllidea) from Indo-Pacific rays of the genus Aetomylaeus

Received 31 July 2013
Garman (Myliobatiformes, Myliobatidae). Folia Parasitol. 4: 321-330.

Khalil L.F. 1994: Order Diphyllidea van Beneden in Carus, 1863. In: L. Khalil, F. Jones and R.A. Bray (Eds.), Keys to the Cestode Parasites of Vertebrates. CAB International, Wallingford, 45-49 pp.

Khalil L.F., Abdul-Salaam J. 1989: Macrobothridium rhynchobati n. g., n. sp. from the elasmobranch Rhynchobatus granulatus, representing a new family of diphyllidean cestodes, the Macrobothridiidae. Syst. Parasitol. 13: 103-109.

Kuchta R., Caira J.N. 2010: Three new species of Echinobothrium (Cestoda: Diphyllidea) from Indo-Pacific stingrays of the genus Pastinachus (Rajiformes: Dasyatidae). Folia Parasitol. 57: 185-196.

Malek M., Caira J.N., Haseli M. 2010: Two new species of Paraorygmatobothrium Ruhnke, 1994 (Cestoda: Tetraphyllidea) from the carcharhinid shark Carcharhinus cf. dussumieri (Müller \& Henle) in the Persian Gulf. Syst. Parasitol. 76: 59-68.

Moore A.B.M. 2011: Elasmobranchs of the Persian (Arabian). Gulf: ecology, human aspects and research priorities for their improved management. Rev. Fish Biol. Fish. 22: 35-61.

Naylor G.J.P., Caira, J.N., Jensen K., Rosana K.A.M., White W.T., LAst P.R. 2012: A DNA sequence based approach to the identification of shark and ray species and its implications for global elasmobranch diversity and parasitology. Bull. Am. Mus. Nat. Hist. 367, 262 pp.

Neifar L., Tyler G.A., Euzet L. 2001: Two new species of Macrobothridium (Cestoda: Diphyllidea) from rhinobatid elasmobranchs in Gulf of Gàbes, Tunisia, with notes on the status of the genus. J. Parasitol. 87: 673-680.

Olson P.D., Caira J.N., Jensen K., Overstreet R.M., Palm H.W., Beveridge I. 2010: Evolution of the trypanorhynch tapeworms: parasite phylogeny supports independent lineages of sharks and rays. Int. J. Parasitol. 40: 223-242.

Palm H.W., Waeschenbach A., Olson P., Littlewood D.T.J. 2009: Molecular phylogeny and evolution of the Trypanorhyncha Diesing, 1863. Mol. Phylogenet. Evol. 52: 351-367.

Tyler G.A. 2006: Tapeworms of elasmobranchs (Part II). A monograph on the Diphyllidea (Platyhelminthes, Cestoda). Bull. Univ. Nebraska State Mus. 20, 145 pp.

Valinasab T. 2013: [List of fishes of the Persian Gulf, Oman Sea and Caspian Sea.] Iranian Fisheries Research and Training Organization, Tehran, 273 pp. (In Persian.) 